\title{
Regulation of gene expression during severe caloric restriction: lack of induction of p85alpha phosphatidylinositol 3-kinase mRNA in skeletal muscle of patients with Type II (non-insulin-dependent) diabetes mellitus
}

\author{
F. Andreelli, M. Laville, N. Vega, J.-P. Riou, H. Vidal \\ INSERM U.449 and Human Nutrition Research Centre of Lyons, René Laënnec Faculty of Medicine and Department of \\ Endocrinology, Diabetology and Nutrition, E. Herriot Hospital, Lyons, France
}

\section{Abstract}

Aims/hypothesis. Alterations in the regulation of gene expression could be involved in the development of Type II (non-insulin-dependent) diabetes mellitus.

Methods. We compared the mRNA concentrations of eight genes encoding proteins involved in insulin action and intermediary metabolism in skeletal muscle of healthy volunteers and Type II diabetic patients. The in vivo regulation of the expression of these genes was investigated after 5 days of hypocaloric $\operatorname{diet}(1045 \mathrm{~kJ} /$ day $)$.

Results. In the basal state, diabetic muscle showed reduced insulin receptor $(-38 \%)$, hexokinase II $(-73 \%)$, glycogen synthase $(-45 \%)$ and lipoprotein lipase $(-70 \%)$ mRNA expression. There was no difference in the mRNA abundances of IRS-1, GLUT 4 , p85 $\alpha$ phosphatidylinositol-3-kinase (p85 $\alpha \mathrm{PI} 3 \mathrm{~K}$ ) or Rad. In both groups, caloric restriction induced weight loss, reduced glycaemia and increased plasma ketone body concentrations. The diet also increased plasma concentrations of fatty acids and decreased whole-body insulin sensitivity in control subjects. In control subjects, the diet increased p $85 \alpha \mathrm{PI} 3 \mathrm{~K}$ $(+146 \%)$, insulin receptor $(+100 \%)$ and $\mathrm{Rad}$ $(+40 \%)$ mRNA concentrations in muscle. In Type II diabetic patients, the diet increased insulin receptor $(+41 \%)$ and $\operatorname{Rad}(+31 \%)$ mRNAs but the expression of p $85 \alpha \mathrm{PI} 3 \mathrm{~K}$ was not modified.

Conclusion/interpretation. The regulation of the expression of $\mathrm{p} 85 \alpha \mathrm{PI} 3 \mathrm{~K}$ is altered during caloric restriction in skeletal muscle of Type II diabetic patients. Because we have shown in an earlier study that there is also a defective regulation of p $85 \alpha \mathrm{PI} 3 \mathrm{~K}$ gene expression in response to insulin, these data support the hypothesis that alterations in the regulation of gene expression could be involved in the pathogenesis of Type II diabetes. [Diabetologia (2000) 43: 356363]

Keywords Phosphatidylinositol-3-kinase, insulin receptor, Rad, hexokinase II, GLUT 4, lipoprotein lipase, insulin resistance.
Type II (non-insulin-dependent) diabetes mellitus is a disease with complex causes, involving interactions between both genetic and environmental factors [1,

Received: 30 September 1999 and in revised form: 3 November 1999

Corresponding author: Dr. H. Vidal, INSERM U.449, Faculté de Médecine René Laënnec, Rue Guillaume Paradin, F69372 Lyon Cédex 08, France.

Abbreviations: RT-cPCR, Reverse transcription-competitive polymerase chain reaction; VLCD, very low calorie diet; Rad, Ras associated with diabetes; $\mathrm{p} 85 \alpha \mathrm{PI} 3 \mathrm{~K}$, p85alpha regulatory subunit of phosphatidylinositol 3-kinase.
2]. Insulin action and glucose, lipid and protein metabolism are perturbed in diabetic patients. Although the initial causes are still not known, these alterations result from changes in the activity of key enzymes, mainly due to post-translational modifications of proteins as well as to changes in their gene expression [1]. Several reports show that the expression of genes coding for proteins involved in insulin action and in intermediate metabolism is altered in the common form of Type II diabetes. For example, expressions of the insulin sensitive glucose transporter (GLUT 4) $[3,4]$ and of the insulin receptor substrate-1 (IRS1) [5] are considerably reduced in adipose tissue. It 
has been also reported that the steady-state mRNA concentrations of $\mathrm{Rad}$ (Ras associated with diabetes) [6], glycogen synthase [7] and hexokinase II [8] are altered in skeletal muscle of diabetic patients. These modifications can result from the adaptation of gene expression to the metabolic perturbations of the disease. Alternatively, they can reflect alterations in the processes that regulate gene expression. In mammalian cells, the transcription of genes and gene networks is controlled by nuclear regulatory proteins (transacting factors) that bind to unique DNA sequences in the promoter region of the regulated genes. Defects in nuclear regulatory proteins of the insulin receptor gene have been found recently in two patients [9] and mutations in trans-acting factors have been involved in the development of subtypes of maturityonset diabetes of the young $[10,11]$. It can be assumed that defective trans-acting factors are also present in the common form of Type II diabetes, leading to an altered regulation of the expression of one or several specific genes.

In addition to abnormal steady state mRNA concentrations [4-8], defects in the regulation of the expression of important genes were also observed in tissues of Type II diabetic patients. It was shown that the rapid induction by insulin of the mRNAs encoding GLUT $4[12,13]$, hexokinase II [14] and the p85a subunit of phosphatidylinositol 3-kinase (p85aPI3K) [15] is impaired in the skeletal muscle of diabetic patients. Because the effects of insulin were studied in patients characterised by insulin resistance, it was difficult to know whether the observed alterations were due to defects at the level of gene transcription or were consequences of reduced insulin action and transmission of the insulin signal to the nucleus. We have found, however, that the induction of $\mathrm{p} 85 \alpha \mathrm{PI} 3 \mathrm{~K}$ mRNA by insulin was not altered in the skeletal muscle of obese non-diabetic subjects who were characterised by similar levels of insulin resistance of whole-body glucose disposal compared with Type II diabetic patients [15]. Although the mechanism of insulin resistance could have been different between the two groups, our results suggest that the impaired regulation of $\mathrm{p} 85 \alpha \mathrm{PI} 3 \mathrm{~K}$ expression reflects a specific defect in the control of gene expression in Type II diabetes, independent of obesity and insulin resistance [15].

To gain more insight into the possible alteration in the regulation of gene expression in tissues of Type II diabetic patients, we have investigated in this work the effect of severe caloric restriction on the expression of selected genes in skeletal muscle. This type of drastic change in nutritional conditions has been shown to be associated with modifications of gene expression in human skeletal muscle [16]. Very low calorie diet, inducing metabolic and hormonal changes, is a common therapy in the treatment of Type II diabetes [17]. Subjects were maintained on a severe hy- pocaloric diet ( $1045 \mathrm{~kJ} /$ day) for 5 days and changes in the mRNA concentrations of eight candidate genes were investigated in skeletal muscle biopsy specimens using reverse transcription-competitive polymerase chain reaction (RT-cPCR).

\section{Subjects and methods}

Subjects. Participants in the study were nine healthy volunteers (eight women and one man, age $=41 \pm 4$ years, BMI $=22 \pm 1$ $\mathrm{kg} / \mathrm{m}^{2}$ ) and eight patients with Type II diabetes mellitus (seven women and one man, age $=51 \pm 3$ years, BMI $=31 \pm 1 \mathrm{~kg} / \mathrm{m}^{2}$, $\mathrm{HbA}_{1 \mathrm{c}}=11 \pm 1 \%$, duration of diabetes $=6.3 \pm 1.3$ years $)$. None of the control subjects had a familial or personal history of diabetes, obesity, dyslipidaemia, hypertension or was taking any medication except for oral contraceptives. The diabetic patients interrupted, under medical control, their usual treatment (oral antidiabetic agents) 1 week before admission. All participants gave their written consent after being informed of the nature, purpose and possible risks of the study. The experimental protocol was approved by the ethics committee of Lyons hospitals and carried out according to French legislation (Huriet law).

Protocols and study design. The subjects participated in a 7-day study protocol. During the 3 days preceding the study, their diet was controlled and standardised (calorie intake of 104 $\left.\mathrm{kJ} \cdot \mathrm{kg}^{-1} \cdot \mathrm{day}^{-1}\right)$. The first and last days of the study protocol were devoted to measurements of metabolic variables including determination of basal and insulin stimulated glucose turn-over rates using euglycaemic hyperinsulinaemic clamp and glucose and lipid oxidations using indirect calorimetry. From the second to the sixth day of the study, the subjects received a very low calorie diet (VLCD) (1045 kJ/day; $45 \%$ carbohydrate, $25 \%$ fat, $30 \%$ protein) that corresponded to about a $90 \%$ reduction in their normal daily calorie intake. Glycaemia, insulinaemia and $\beta$-hydroxybutyrate concentrations were measured daily using methods described previously [18]. Fasting glucagon, free T3 and $24 \mathrm{~h}$-free urinary cortisol were determined before and at the end of the diet.

Basal glucose turn-over rate was determined by dilution tracer methodology using a primed [6,6-2H2]glucose (Eurisotop, St Aubain, France) infusion $\left(0.11 \mu \mathrm{mol} \cdot \mathrm{kg}^{-1} \cdot \mathrm{min}^{-1}\right)$ for $3 \mathrm{~h}$ as described previously [18]. Then a 3-h euglycaemic hyperinsulinaemic clamp was started by the infusion of insulin (Actrapid Novo, Copenhagen, Denmark) at a rate of 450 $\mathrm{pmol} \cdot \mathrm{m}^{-2} \cdot \mathrm{min}^{-1}[18,19]$. Primed $[6,6-2 \mathrm{H} 2]$ glucose was infused $\left(0.55 \mu \mathrm{mol} \cdot \mathrm{kg}^{-1} \cdot \mathrm{min}^{-1}\right)$ during the clamp to determine glucose turn-over rate while any decrease in blood glucose was prevented by adapted infusion of $20 \%$ glucose solution (Aguettant, Lyons, France). For the determination of glycaemia, insulinaemia and [6,6-2H2]glucose isotopic enrichment, blood samples were drawn every $10 \mathrm{~min}$ both during the last 30 min of the basal period and during the last hour of the hyperinsulinaemic clamp. Urine was collected to determine glucosuria, $\beta$-hydroxybutyrate and nitrogen concentrations. Metabolite and hormone concentrations were measured using enzymatic methods and radioimmunoassays. Plasma isotopic enrichment of [6,6-2H2]glucose was determined by gas chromatography-mass spectrometry (5971 MSD, Hewlett-Packard, Paolo Alto, Calif., USA) as described [18]. Glucose turn-over rates were calculated during the basal state and the last hour of the hyperinsulinaemic clamp using steady-state equations. For the Type II diabetic patients, glucosuria was substracted from glucose turn-over rates to calculate glucose utilisation. 
Table 1. Sequences of the RT-cPCR primers and sizes of the amplified products

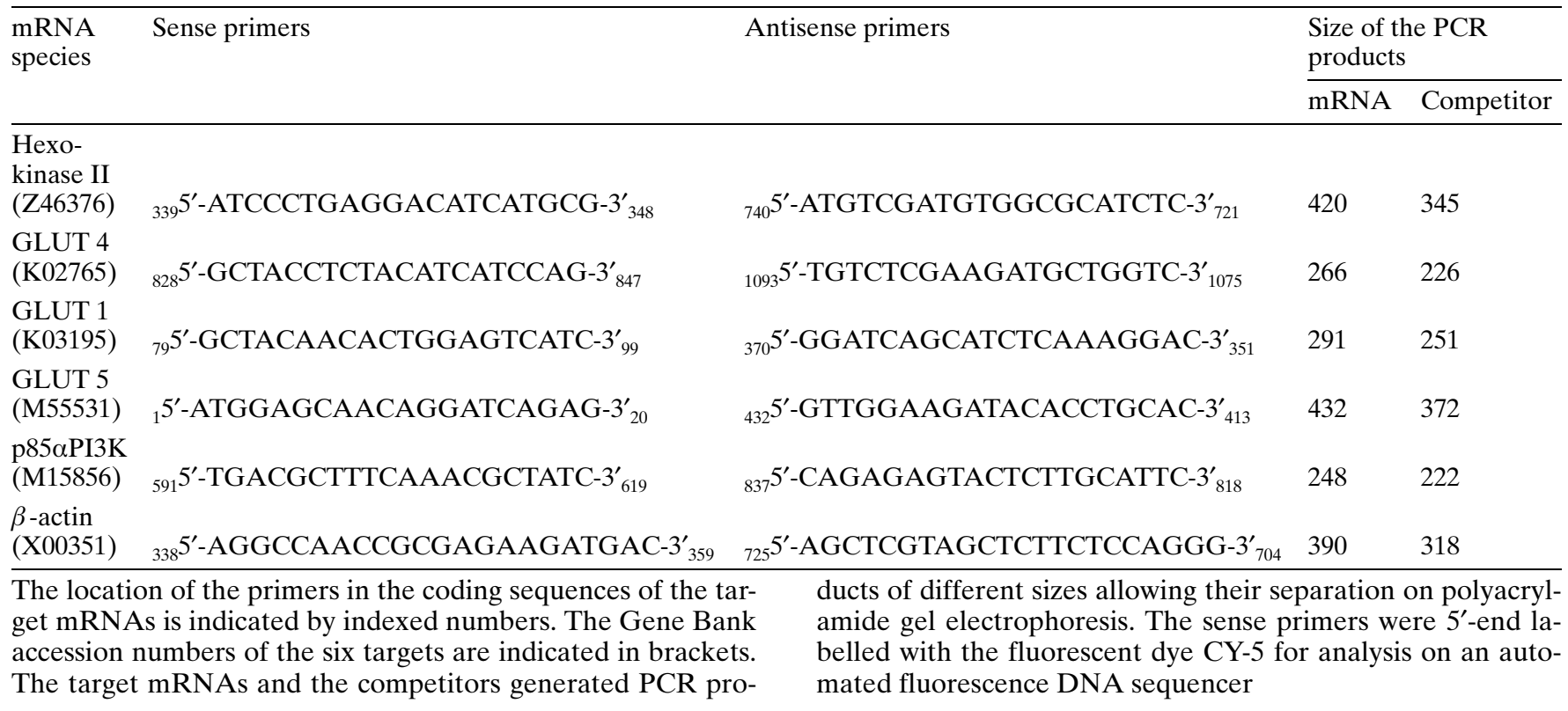

Respiratory exchange measurements were done to estimate glucose and lipid oxidation rates during the last hour of both the basal and hyperinsulinaemic periods of the clamp. Measurements were made using a computerised flow-through canopy gas-analyser system (Deltatrac Metabolic Monitor, Datex, Helsinki, Finland) [18]. When required, substrate oxidation and energy expenditure values were corrected for ketogenesis as proposed by Frayn [20]. After VLCD, carbohydrate oxidation was corrected for gluconeogenesis from amino acids, assuming that three-quarters of degradated proteins were converted into glucose [21].

Muscle biopsy specimens. Muscle biopsy specimens were taken after an overnight fast in the morning of the first day of the protocol and in the morning of the last day, after 5 days of caloric restriction. The specimens were taken under local anaesthesia (2\% lidocaine) as described previously [15, 19]. Briefly, muscle samples were obtained by percutaneous biopsy of the vastus lateralis muscle using Weil Blakesley pliers $(53 \pm 5 \mathrm{mg}$, $n=34$, range $32-147$, no difference in size between samples from control and Type II diabetic subjects or before and after diet). Tissue samples were immediately frozen in liquid nitrogen and stored at $-80^{\circ} \mathrm{C}$ for further analysis.

Total RNA preparation. Tissue samples were pulverised in liquid nitrogen and total RNA was prepared according to a modification of a previously reported procedure [22]. In addition to absorbance measurements, concentration and integrity of the RNA preparations were carefully verified in agarose gels stained with ethidium bromide. The yield of total RNA was $25 \pm 3 \mu \mathrm{g}$ per $100 \mathrm{mg}$ of muscle (wet weight) with no statistically significant difference between muscle from control and diabetic subjects, before or after the hypocaloric diet. Total RNA solutions were stored at $-80^{\circ} \mathrm{C}$ until quantification of the target mRNAs.

Quantification of target $m R N A$ s. The concentrations of the eight selected mRNAs were measured by RT-cPCR [23, 24]. The method relies on the use of a competitor DNA molecule during the amplification process, after a specific reverse tran- scription reaction. Insulin receptor, IRS-1, Rad, glycogen synthase and lipoprotein lipase mRNAs were quantified using the multispecific heterologous competitor DNA that was constructed and validated previously [19]. For the assays of the mRNAs encoding GLUT 4, p85 $\alpha$ PI3K and hexokinase II we had designed and elaborated a new competitor DNA molecule. In addition to these three mRNAs, this new multispecific homologous competitor [24] allows the quantification of GLUT 1 , GLUT 5 and $\beta$-actin mRNA concentrations. For the construction, a cDNA fragment of each target mRNA was obtained by RT-PCR from human skeletal muscle using specific sense and antisense primers (Table 1) and high-fidelity $p f u$ DNA polymerase (Stratagen, La Jolla, Calif., USA). Each fragment was subcloned (pGEM-T Vector System, Promega, Charbonnières, France) and used to generate a specific competitor using a PCR-based deletion/mutagenesis method [25]. Each competitor gave rise to a PCR product that was slightly shorter in size than the normal cDNA (Table 1). To generate the complete molecule, individual competitor cDNAs were associated together using a PCR overlap extension method [25] and high-fidelity $p f u$ DNA polymerase. The full length (1733 bp) multispecific homologous competitor was then subcloned in pGEM. Its sequence, verified by automated DNA sequencing, matched perfectly with the target mRNA sequences reported in the Gene Bank. The organisation of the individual competitors in the complete molecule is the following: (from the T7 RNA polymerase promoter in pGEM) hexokinase, GLUT 4, GLUT 1, GLUT 5, $\beta$-actin and p85 $\alpha$ PI3K. The RTcPCR assays of the six targets were validated using known amounts ( 0.1 to $50 \mathrm{amol})$ of RNAs that were synthesised by in vitro transcription (Riboprobe System, Promega) and that correspond to part of the target mRNAs, as recommended previously [24]. For the assays, working solutions of the competitor plasmids $\left(20 \mathrm{amol} / \mu \mathrm{l}\right.$ to $\left.10^{-3} \mathrm{amol} / \mu \mathrm{l}\right)$ were prepared by serial dilutions in $10 \mathrm{mmol} / \mathrm{l}$ TRIS-HCL ( $\mathrm{pH} 8.3$ ), 1 mmol/1 EDTA buffer.

The conditions of the RT-cPCR reactions have been described in detail previously $[19,24]$. For each mRNA, the specific first strand cDNA was synthesised from $0.1 \mu \mathrm{g}$ of total RNA added in the RT reaction. During the PCR, we used 
Table 2. Metabolic characteristics of the subjects before and after caloric restriction

\begin{tabular}{|c|c|c|c|c|}
\hline & \multicolumn{2}{|c|}{ Control subjects $(n=9)$} & \multicolumn{2}{|c|}{ Type II diabetic $(n=8)$} \\
\hline & before diet & after diet & before diet & after diet \\
\hline Glycaemia (mmol/1) & $4.6 \pm 0.1$ & $3.7 \pm 0.2^{\mathrm{a}}$ & $12.7 \pm 1.0^{\mathrm{d}}$ & $9.1 \pm 1.0^{\mathrm{a}}$ \\
\hline $\mathrm{NEFA}(\mathrm{mmol} / \mathrm{l})$ & $0.44 \pm 0.05$ & $0.86 \pm 0.09^{\mathrm{b}}$ & $0.76 \pm 0.04^{\mathrm{d}}$ & $0.75 \pm 0.05$ \\
\hline Triglycerides $(\mathrm{mmol} / \mathrm{l})$ & $0.7 \pm 0.1$ & $0.5 \pm 0.1^{\mathrm{a}}$ & $2.4 \pm 0.7^{\mathrm{d}}$ & $1.6 \pm 0.3^{\mathrm{b}}$ \\
\hline$\beta$-hydroxybutyrate $(\mathrm{mmol} / \mathrm{l})$ & $0.12 \pm 0.02$ & $2.1 \pm 0.3^{b}$ & $0.7 \pm 0.4^{\mathrm{c}}$ & $1.5 \pm 0.5^{b}$ \\
\hline $\begin{array}{l}\text { Glucose oxidation rates: } \\
\text { Basal }\left(\mu \mathrm{mol} \cdot \mathrm{m}^{-2} \cdot \mathrm{min}^{-1}\right) \\
\text { Clamp }\left(\mu \mathrm{mol} \cdot \mathrm{m}^{-2} \cdot \mathrm{min}^{-1}\right)\end{array}$ & $\begin{array}{l}247 \pm 41 \\
659 \pm 34\end{array}$ & $\begin{array}{l}143 \pm 26^{\mathrm{b}} \\
300 \pm 51^{\mathrm{b}}\end{array}$ & $\begin{array}{l}297 \pm 34 \\
511 \pm 47^{\mathrm{c}}\end{array}$ & $\begin{array}{l}287 \pm 19 \\
317 \pm 37^{\mathrm{a}}\end{array}$ \\
\hline $\begin{array}{l}\text { Lipid oxidation rates: } \\
\text { Basal }\left(\mu \mathrm{mol} \cdot \mathrm{m}^{-2} \cdot \min ^{-1}\right)\end{array}$ & $120 \pm 14$ & $158 \pm 16^{\mathrm{a}}$ & $136 \pm 13$ & $153 \pm 11$ \\
\hline
\end{tabular}

Metabolic variables were determined before and after 5 days of VLCD in both groups of subjects. Data are means \pm SEM; ${ }^{\mathrm{a}} p<0.05$ and ${ }^{\mathrm{b}} p<0.01$ after vs before diet; ${ }^{\mathrm{c}} p<0.05$ and ${ }^{\mathrm{d}} p<0.01$ Type II diabetic vs control subjects before diet

sense primers that were 5 '-end labelled with Cy-5 fluorescent dye (Eurogentec, Seraing, Belgium). The PCR products were then analysed with an automated laser fluorescence DNA sequencer (ALFexpress, Pharmacia, Uppsala, Sweden) in $4 \%$ denaturating polyacrylamide gels [15]. The amounts of PCR products (competitor and target) were calculated by integrating peak areas using the Fragment Manager software from Pharmacia. To determine the initial concentration of target mRNA, the logarithm of the peak surface ratio of competitor to target was plotted against the logarithm of the amount of competitor added into the PCR medium. The initial concentration of the target was determined at the competition equivalence point as described [24].

Presentation of results. The RT-competitive PCR assays that were used in this study allow the determination of the real quantity of a target mRNA [24]. Thus, the results are presented as absolute concentrations, in amol/ $\mu \mathrm{g}$ of total RNA. In addition, to accurately determine the effect of VLCD, total RNA of the two muscle biopsy specimens from the same subject (before and after diet) were prepared simultaneously. The assay of the different target mRNAs were always made in parallel in the same run of PCR and with the same working solutions of competitor.

The data are presented as means \pm SEM. Statistical significance of the results was determined using Mann-Whitney non-parametric test when comparing Type II diabetic and control subjects. Wilcoxon non-parametric test for paired values was used when comparing mRNA concentrations before and after VLCD in the same group of subjects. The threshold for significance was set at $p=0.05$.

\section{Results}

Hormonal and metabolic variables in Type II diabetic patients and in control subjects. Before diet, Type II diabetic patients had higher circulating concentrations of glucose, insulin, non-esterified fatty acids (NEFA), triglycerides and $\beta$-hydroxybutyrate than control subjects (Table 2). The two groups had similar basal glucose utilization rates (Table 2). Glucose clearance was, however, lower in Type II diabetics than in control subjects $(47 \pm 8$ vs $97 \pm 4 \mathrm{ml}$. $\left.\mathrm{m}^{-2} \cdot \min ^{-1}, p<0.02\right)$. Basal glucose and lipid oxidation rates were similar in the two groups of subjects (Table 2). During the hyperinsulinaemic clamp, insulinaemia $(835 \pm 70$ and $1053 \pm 115 \mathrm{pmol} / \mathrm{l}$, in control and in Type II diabetic subjects, NS) and glycaemia $(4.6 \pm 0.3$ and $5.2 \pm 0.3$, in control and in Type II diabetic subjects, NS) were maintained at similar values. Under these conditions, insulin-stimulated glucose disposal rates were considerably (more than 60\%) reduced in the Type II diabetic patients (Table 2). Both insulin-stimulated glucose oxidation rates (Table 2) and non-oxidative glucose disposal rates $\left(282 \pm 101\right.$ vs $1161 \pm 144 \mu \mathrm{mol} \cdot \mathrm{m}^{-2} \cdot \mathrm{min}^{-1}$, Type II diabetic vs control subjects, $p<0.01$ ) were lower in Type II diabetic patients.

During the 5 days of VLCD, the control subjects lost weight $(2.6 \pm 0.2 \mathrm{~kg})$. The diet produced significant decreases in basal glucose and triglyceride concentrations, whereas circulating NEFA and $\beta$-hydroxybutyrate concentrations increased considerably (Table 2). Glycerol concentrations were also increased during VLCD $(53 \pm 6$ vs $93 \pm 11 \mu \mathrm{mol} / \mathrm{l}$, before vs after VLCD, $p<0.01)$. Basal plasma concentrations of glucagon, T3 and cortisol, and free urinary cortisol were not changed after VLCD (data not shown). Basal rates of total glucose utilisation (i.e. oxidative and non-oxidative utilisation) and glucose oxidation were decreased whereas lipid oxidation rates were increased (Table 2). Resting metabolic rate was reduced by VLCD $(3549 \pm 129$ vs $3472 \pm 99$ $\mathrm{kJ} \cdot \mathrm{m}^{-2} \cdot$ day $^{-1}$, before vs after VLCD, $\left.p<0.01\right)$. During the hyperinsulinaemic clamp, the levels of glycae$\mathrm{mia}(4.6 \pm 0.3 \mathrm{mmol} / \mathrm{l})$ and insulinaemia $(853 \pm 57$ $\mathrm{pmol} / \mathrm{l})$ were similar to those obtained during the clamp made before diet. Insulin-stimulated total glucose utilisation and oxidation rates (Table 2) and 


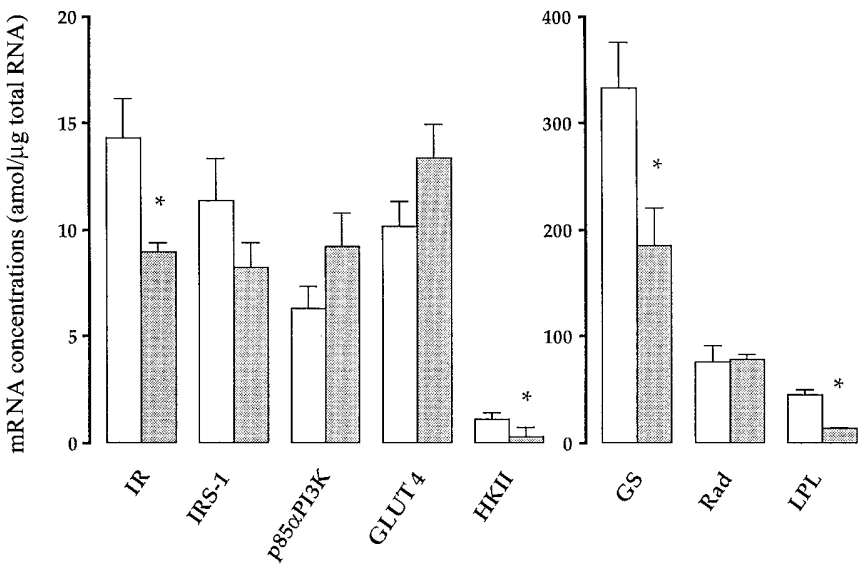

Fig. 1. Expression profiles of the mRNA of the eight target genes in skeletal muscle from control and Type II diabetic subjects, in the basal state. Specific mRNA concentrations were quantitated by RT-cPCR in total RNA preparations from vastus lateralis skeletal muscle biopsy specimens from nine control and eight Type II diabetic subjects. Open boxes: control subjects, black boxes: diabetic patients. IR, insulin receptor; HKII, hexokinase II; GS, glycogen synthase and LPL, lipoprotein lipase. Data are means $\pm \mathrm{SEM}, * p<0.05$ vs control subjects using the non-parametric test of Mann-Whitney

non-oxidative glucose disposal rates $(1161 \pm 144$ vs $741 \pm 123 \mu \mathrm{mol} \cdot \mathrm{m}^{-2} \cdot \mathrm{min}^{-1}$, before vs after VLCD, $p<0.01)$ were decreased. These results indicate that the 5 days of VLCD induced a state of insulin resistance in control subjects.

Similarly to the situation in control subjects, the Type II diabetic patients lost weight $(2.4 \pm 0.7 \mathrm{~kg})$ during VLCD. Basal concentrations of glucagon, T3 and cortisol, and free urinary cortisol were not changed. The caloric restriction produced significant decreases in glycaemia and in triglyceride concentrations whereas there was a pronounced increase in circulating $\beta$-hydroxybutyrate concentrations (Table 2 ). Plasma concentrations of NEFA (Table 2) and glycerol (76 \pm 7 vs $64 \pm 5 \mu \mathrm{mol} / 1$, before vs after VLCD, NS) were not modified by VLCD, indicating a lack of induction of lipolysis in Type II diabetic patients. Basal glucose utilisation rates were lowered by the dietary restriction (Table 2) and the basal resting metabolic rate decreased $\left(3705 \pm 152\right.$ vs $3469 \pm 103 \mathrm{~kJ} \cdot \mathrm{m}^{-2}$. day $^{-1}$, before vs after VLCD,$\left.p<0.01\right)$. During the hyperinsulinaemic clamp, levels of glycaemia $(5.4 \pm 0.3)$ and insulinaemia $(928 \pm 71 \mathrm{pmol} / \mathrm{l})$ were not different from those obtained during the clamp made before diet. Insulin-stimulated glucose utilisation rates were not modified by VLCD in Type II diabetic patients (Table 2). The 5 days of caloric restriction decreased insulin-stimulated glucose oxidation rates (Table 2), whereas insulin-stimulated non-oxidative glucose disposal rates did not change $\left(438 \pm 132\right.$ vs $281 \pm 101 \mu \mathrm{mol} \cdot \mathrm{m}^{-2} \cdot \mathrm{min}^{-1}$, after vs before VLCD).
Expression of the target $m R N A s$ in skeletal muscle. Figure 1 shows the expressions of the eight selected mRNAs in skeletal muscle of control and Type II diabetic subjects. Insulin receptor $(-38 \%, p=0.015)$, hexokinase II $(-73 \%, p=0.002)$, glycogen synthase $(-45 \%, p=0.044)$, and lipoprotein lipase $(-70 \%$, $p=0.001)$ mRNA concentrations were significantly lower in Type II diabetic patients compared with control subjects. Regarding the expression of insulin receptor, the percentage of the isoform with exon 11 was higher in muscle from Type II diabetic patients than in that from control subjects $(62 \pm 5 \%$ vs $43 \pm 6 \%$ of total insulin receptor mRNA, $p<0.05)$. On the other hand, skeletal muscle mRNA expression of IRS-1 $(p=0.27)$, p85aPI3K $(p=0.21)$, GLUT 4 $(p=0.15)$ and $\operatorname{Rad}(p=0.31)$ were not different in the two groups of subjects (Fig. 1). We also quantified the expression of the gene coding for $\beta$-actin as a reference gene. There was no difference in the mean concentrations of $\beta$-actin mRNA in muscle from control and Type II diabetic subjects $(2055 \pm 327$ and $2711 \pm 753 \mathrm{amol} / \mu \mathrm{g}$ of total RNA, in control and in Type II diabetic, respectively; $p=0.64$ ).

Effects of VLCD on the expression of the target $m R N A s$. The mRNA expression of insulin receptor $(100 \pm 34 \%, \quad p=0.015), \quad$ p $85 \alpha \mathrm{PI} 3 \mathrm{~K} \quad(146 \pm 51 \%$, $p=0.008)$ and $\operatorname{Rad}(40 \pm 16 \%, p=0.011)$ were significantly increased after 5 days of VLCD in the skeletal muscle of control subjects (Fig. 2). In Type II diabetic patients, the diet also induced a significant increase in insulin receptor $(41 \pm 15 \%, p=0.049)$ and $\mathrm{Rad}$ $(31 \pm 8 \%, p=0.025)$ mRNA concentrations. Importantly, there was no induction of $\mathrm{p} 85 \alpha \mathrm{PI} 3 \mathrm{~K}$ expression $(12 \pm 13 \%, p=0.735)$. The VLCD did not affect the expressions of IRS-1, GLUT 4, hexokinase II, glycogen synthase and lipoprotein lipase mRNAs in muscle of either control or Type II diabetic patients. Regarding insulin receptor, both mRNA variants, with and without exon 11, were increased in the two groups. Thus, their relative expression was not modified by VLCD $(43 \pm 5 \%$ and $66 \pm 4 \%$ of mRNA with exon 11 after diet in control and Type II diabetic subjects, respectively; not different from the values obtained before VLCD). Finally, the concentrations of $\beta$-actin mRNA were not affected by VLCD in the two groups $(1779 \pm 310$ and $2017 \pm 513 \mathrm{amol} / \mu \mathrm{g}$ of total RNA in control and in Type II diabetic subjects after VLCD). Figure 3 shows the individual data of p $85 \alpha \mathrm{PI} 3 \mathrm{~K}$ mRNA concentrations before and after VLCD, clearly illustrating the lack of induction in the skeletal muscle of Type II diabetic patients.

\section{Discussion}

This study was carried out to identify alterations in the regulation of the expression of one or several 


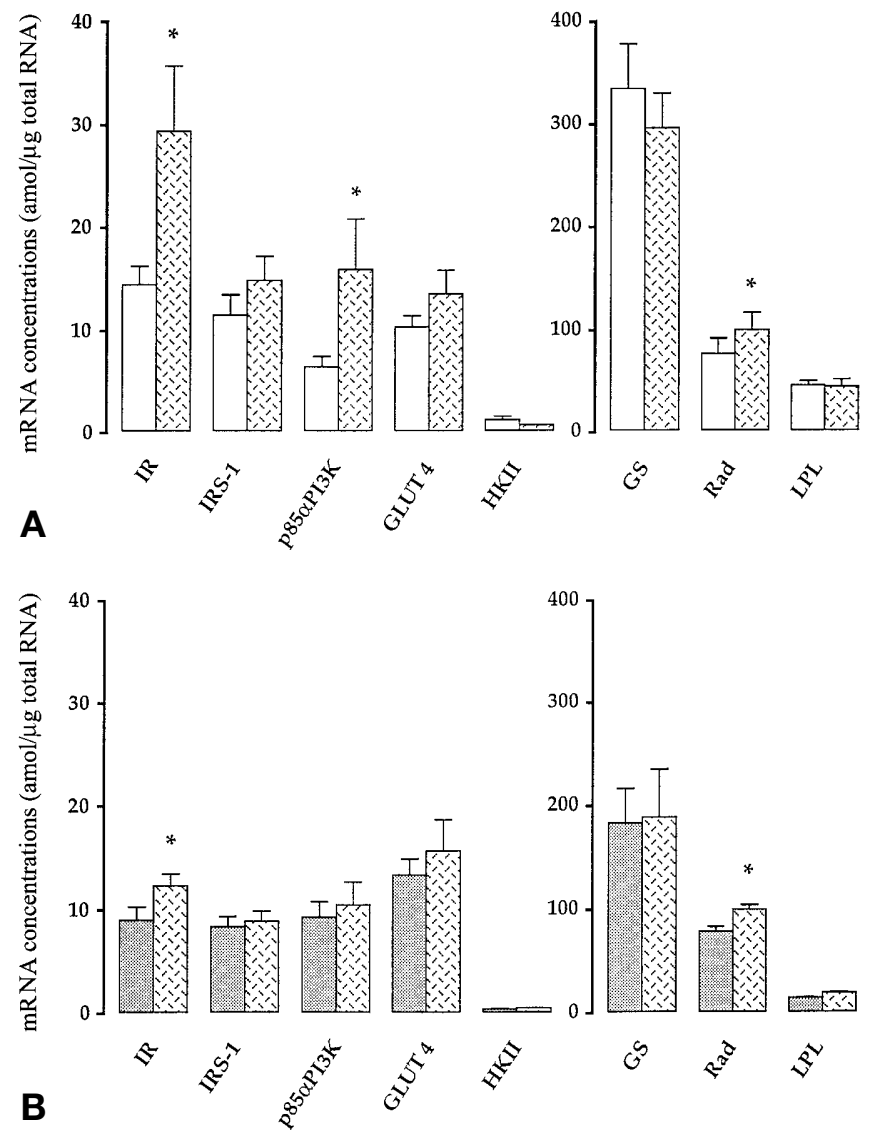

Fig. 2A, B. Effects of 5 days of caloric restriction $(1045 \mathrm{~kJ} /$ day) on the expression of the target mRNAs in skeletal muscle. Specific mRNA concentrations were measured as indicated in the Material and methods section. Open and black boxes represent the values obtained before VLCD and hatched boxes corresponded to the values determined after VLCD. A Control subjects, B Type II diabetic patients. IR, insulin receptor; HKII, hexokinase II; GS, glycogen synthase and LPL, lipoprotein lipase. Data are means \pm SEM, ${ }^{*} p<0.05$ using the non-parametric test of Wilcoxon for paired data

key genes in skeletal muscle of Type II diabetic patients. We investigated the coordinated regulation of the expression of eight mRNAs that encode proteins involved in insulin action and in intermediary metabolism. We report a comparison of the expression profiles of these important genes in skeletal muscle of healthy control subjects and Type II diabetic patients. In the basal state, the Type II diabetic patients had statistically significant reductions in the mRNA concentrations of insulin receptor, hexokinase II, glycogen synthase and lipoprotein lipase.

Reduced expression of glycogen synthase [7] and hexokinase II [8] in skeletal muscle of Type II diabetic patients have been documented previously. Little is known about the regulation of the expression of lipoprotein lipase in human skeletal muscle. Lipoprotein lipase mRNA has never been quantified in muscle of Type II diabetic patients. The decreased mRNA expression observed in our study is in keeping with the
Control Type II diabetic
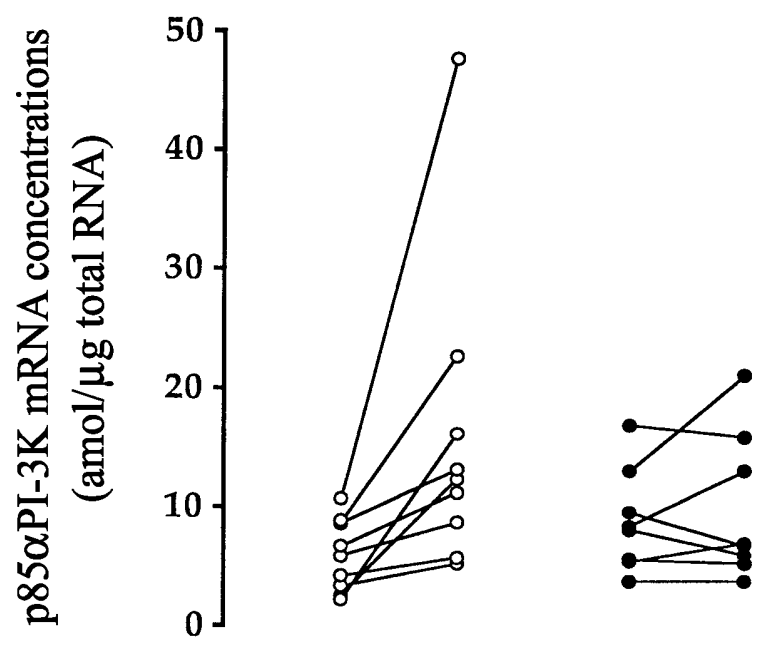

Fig. 3. Effects of 5 days of caloric restriction on the mRNA expression of $\mathrm{p} 85 \alpha \mathrm{PI} 3 \mathrm{~K}$ in skeletal muscle of control and Type II diabetic subjects

reduced lipoprotein lipase activity found in muscle of insulin resistant subjects [26].

These data also confirm our previous report showing that IRS- 1 and $\mathrm{p} 85 \alpha \mathrm{PI} 3 \mathrm{~K}$ mRNA concentrations were not altered in muscle of Type II diabetic patients in the basal state [15]. In contrast to that work, we found here a significant reduction in the concentrations of total insulin receptor $\mathrm{mRNA}$ that might be in accordance with the lower number of insulin binding sites in muscle of Type II diabetic subjects [27, 28]. A possible explanation for the discrepancy between the present and our previous results [15] could be because the Type II diabetic patients in the present study were more insulin resistant than the subjects in the previous one (insulin-stimulated glucose uptake rates during the clamp of about $690 \mu \mathrm{mol} \cdot \mathrm{m}^{-2} \cdot \mathrm{min}^{-1}$ vs $1045 \mu \mathrm{mol} \cdot \mathrm{m}^{-2} \cdot \mathrm{min}^{-1}$ in [15]). They also had a higher fasting insulinaemia and higher $\mathrm{HbA}_{1 \mathrm{c}}$. These metabolic differences could thus contribute to the reduced mRNA expression of insulin receptor [29]. The relative expression of the insulin receptor mRNA variant with exon 11 was slightly higher in the muscle of the Type II diabetic subjects in the present study. Increased expression of the insulin receptor isoform with exon 11 has been found in skeletal muscle of Type II diabetic patients [30] but most of the subsequent studies did not confirm this result [31,32]. Taken together, these results suggest that the expression of insulin receptor gene is variable in Type II diabetic patients and can be related to their metabolic state, as suggested from animal model studies [33].

Initially Rad, a Ras-like GTPase identified by subtraction cloning, was shown to be overexpressed in Type II diabetic muscle [6]. This result was questioned in a study [34] that that found a similar expression of Rad mRNA and protein in control and diabet- 
ic muscles. In agreement with this last study, we found here that Rad mRNA concentrations were similar in the skeletal muscle of control and Type II diabetic subjects. Finally, as generally observed [35], we did not find a difference in the mRNA concentrations of the insulin-dependent glucose transporter GLUT 4 in the muscle of control and Type II diabetic subjects.

Steady-state mRNA concentrations, as observed in the basal state, could reflect adaptations of gene expression to the metabolic state of the subjects. Alternatively, they could also be related to alterations in the regulation of these genes. To characterise these potential alterations, we studied the effects of a severe reduction in calorie intake on the mRNA expression of the eight selected target genes. In control and in Type II diabetic subjects, 5 days of VLCD produced statistically significant decreases in body weight, basal resting metabolic rate and glycaemia as well as an increase in ketone body concentrations. Circulating concentrations of NEFA and glycerol did not, however, change in diabetic patients but were increased in the control group, suggesting a lack of induction of lipolysis during fasting in Type II diabetes, as observed previously in some [36] but not all [21] studies. It is also important to note that the diet decreased insulin sensitivity in the healthy lean subjects. In these latter, insulin receptor, $\mathrm{p} 85 \alpha \mathrm{PI} 3 \mathrm{~K}$ and Rad mRNAs were significantly increased after the 5 days of caloric restriction. In contrast, insulin receptor and Rad mRNA concentrations were increased in muscle of Type II diabetic patients whereas the mRNA expression of p $85 \alpha \mathrm{PI} 3 \mathrm{~K}$ did not change. Insulin-receptor substrate1, GLUT 4, hexokinase II, glycogen synthase and lipoprotein lipase mRNA expression were not changed after VLCD in both groups.

With regard to the reduction in insulin sensitivity, the increase in insulin receptor and p85aPI3K mRNA expression in muscle of control subjects seemed thus to be a compensatory mechanism at the level of gene expression. Because insulin receptor and Rad mRNA concentrations increased in the muscle in both groups, whereas p $85 \alpha \mathrm{PI} 3 \mathrm{~K}$ mRNA did not change in the diabetic subjects, a specific defect in the regulation of the expression of this gene might occur in the skeletal muscle of Type II diabetic patients. It could be argued, however, that the lack of change in p $85 \alpha$ PI3K mRNA during VLCD was related to the lower induction of insulin receptor mRNA expression in Type II diabetic compared with control subjects ( $41 \%$ vs $100 \%)$. Notably, we have shown previously that insulin induces $\mathrm{p} 85 \mathrm{\alpha PI} 3 \mathrm{~K}$ gene expression in human skeletal muscle [15]. Plasma insulin concentrations were not, however, modified or tended to decrease during VLCD, suggesting that insulin did not play a major part in the changes in p $85 \alpha \mathrm{PI} 3 \mathrm{~K}$ mRNA expression during dieting.

We have already shown a defective regulation of p $85 \alpha \mathrm{PI} 3 \mathrm{~K}$ gene expression in muscle and adipose tis- sue of Type II diabetic patients during a hyperinsulinaemic euglycaemic clamp study [15]. Others have found that $\mathrm{p} 85 \alpha \mathrm{PI} 3 \mathrm{~K}$ protein content was increased by insulin in normal muscle but not in muscle from Type II diabetic patients [37]. Therefore, the regulation of $\mathrm{p} 85 \alpha \mathrm{PI} 3 \mathrm{~K}$ gene expression seems to be altered in different metabolic situations. During the hyperinsulinaemic euglycaemic clamp, plasma concentrations of insulin increased whereas NEFA and ketone body concentrations decreased greatly [15]. During VLCD, insulin concentration did not change, glycaemia decreased and NEFA and ketone body concentrations increased considerably (this study). Under both conditions, $\mathrm{p} 85 \alpha \mathrm{PI} 3 \mathrm{~K}$ mRNA expression was statistically significantly increased in skeletal muscle in control subjects but not in Type II diabetic patients. Note however, the basal steady-state mRNA concentrations of p $85 \alpha \mathrm{PI} 3 \mathrm{~K}$ were not different between control and diabetic subjects, indicating that the defect in the regulation of the gene coding for $\mathrm{P} 85 \alpha \mathrm{P} 13 \mathrm{~K}$ is detectable only during large changes in metabolism.

During severe caloric restriction, the increase in NEFA could participate in the up-regulation of p $85 \alpha$ PI3K mRNA expression in control subjects. The defective regulation observed in diabetic muscle could be due to the lack of change in circulating NEFA in these patients. The rates of lipid oxidation after the diet were, however, similar in control and in Type II diabetic subjects. Moreover, the defect in the regulation of the gene coding for $\mathrm{p} 85 \alpha \mathrm{PI} 3 \mathrm{~K}$ has been also observed during hyperinsulinaemic clamp [15], a situation during which plasma concentrations of NEFA were considerably decreased in both groups. Therefore, plasma NEFA does not seem to play a major part in the alteration observed.

Altered regulation of $\mathrm{p} 85 \alpha \mathrm{PI} 3 \mathrm{~K}$ mRNA expression could be due to mutation(s) in the promoter region of the gene. The sequence of the human promoter of the gene coding for $\mathrm{p} 85 \alpha \mathrm{PI} 3 \mathrm{~K}$ is not yet available. A recent genetic study does not, however, indicate a statistically significant association between this gene and insulin resistance in Type II diabetes [38]. Alternatively, this alteration could be a marker of a more widespread defect in the regulation of gene expression. In addition to $\mathrm{p} 85 \alpha \mathrm{PI} 3 \mathrm{~K}$ [15], altered regulation by insulin of GLUT $4[12,13]$ and hexokinase II [14] have been found in skeletal muscle of Type II diabetic patients. It seems therefore that the regulation of a network of genes involved in insulin action might be affected. It is possible that a common mechanism controls the expression of these genes (like a common trans-acting factor).

Acknowledgements. The authors acknowledge C. Urbain, J. Peyrat and M. Odeon for excellent technical assistance. This work was supported in part by research grants from INSERM (PROGRES No 4P020D) and from ALFEDIAM-Novo Nordisk. 


\section{References}

1. Kahn RC (1994) Insulin action, diabetogenes, and the cause of Type II diabetes. Diabetes 43: 1066-1084

2. Yki-Järvinen H (1995) Role of insulin resistance in the pathogenesis of NIDDM. Diabetologia 38: 1378-1388

3. Garvey WT, Maianu L, Huecksteadt TP, Birnbaum MJ, Molina JM, Ciaraldi TP (1991) Pretranslational suppression of a glucose transporter protein causes insulin resistance in adipocytes from patients with non-insulin-dependent-diabetes mellitus and obesity. J Clin Invest 87: 1072-1081

4. Sinha MK, Raineri-Maldonado C, Buchanan C et al. (1991) Adipose tissue glucose transporters in NIDDM: decreased levels of muscle/fat isoform. Diabetes 40: 472-477

5. Rondinone CM, Wang LM, Lonnroth P, Wesslau C, Pierce JH, Smith U (1997) Insulin receptor substrate (IRS) 1 is reduced and IRS-2 is the main docking protein for phosphatidylinositol 3-kinase in adipocytes from subjects with non-insulindependent diabetes mellitus. Proc Natl Acad Sci USA 94: 4171-4175

6. Reynet C, Kahn CR (1993) Rad: a member of the Ras family overexpressed in muscle of Type II diabetic humans. Science 262: $1441-1444$

7. Vestergaard H, Lund S, Larsen FS, Bjerrum OJ, Pedersen O (1993) Glycogen synthase and phosphofructokinase protein and mRNA levels in skeletal muscle from insulin-resistant patients with non-insulin-dependent diabetes mellitus. J Clin Invest 91: 2342-2350

8. Vestergaard H, Bjorbaek C, Hansen T, Larsen FS, Granner DK, Pedersen O (1995) Impaired activity and gene expression of hexokinase II in muscle from non-insulin-dependent diabetes mellitus patients. J Clin Invest 96: 2639-2645

9. Brunetti A, Brunetti L, Foti D, Accili D, Goldfine ID (1997) Human diabetes associated with defects in nuclear regulatory proteins for the insulin receptor gene. J Clin Invest 97: 258-262

10. Yamagata K, Oda N, Kaisaki PJ et al. (1996) Mutations in the hepatocyte nuclear factor-1 a gene in maturity-onset diabetes of the young (MODY3). Nature 384: 455-458

11. Yamagata K, Furuta H, Oda N et al. (1996) Mutations in the hepatocyte nuclear factor-4 a gene in maturity-onset diabetes of the young (MODY1). Nature 384: 458-460

12. Andersen PH, Lund S, Vestergaard H, Junker S, Kahn BB, Pedersen O (1993) Expression of the major insulin regulatable glucose transporter (Glut 4) in skeletal muscle of non insulindependent diabetic patients and healthy subjects before and after insulin infusion. J Clin Endocrinol Metab 77: 27-32

13. Schalin-Jänti C, Yki-Järvinen H, Koranyi L et al. (1994) Effect of insulin on Glut $4 \mathrm{mRNA}$ and protein concentrations in skeletal muscle of patients with NIDDM and their first-degree relatives. Diabetologia 37: 401-407

14. Pendergrass M, Koval J, Vogt C et al. (1998) Insulin-induced hexokinase II expression is reduced in obesity and NIDDM. Diabetes 47: 387-394

15. Andreelli F, Laville M, Ducluzeau PH et al. (1999) Defective regulation of phosphatidylinositol-3-kinase gene expression in skeletal muscle and adipose tissue of non-insulin-dependent dibetes mellitus patients. Diabetologia 42: 358-364

16. Millet L, Vidal H, Andreelli F et al. (1997) Increased uncoupling protein-2 and -3 mRNA expression during fasting in obese and lean humans. J Clin Invest 100: 2665-2670

17. Wing RR (1995) Use of very-low-calorie diets in the treatment of obese persons with non-insulin-dependent diabetes mellitus. J Am Diet Assoc 95: 569-572

18. Laville M, Rigalleau V, Riou JP, Beylot M (1995) Respective role of plasma non esterified fatty acids oxidation and total lipid oxidation in lipid-induced insulin resistance. Metabolism 44: 639-644

19. Laville M, Auboeuf D, Khalfallah Y, Vega N, Riou JP, Vidal H (1996) Acute regulation by insulin of phosphatidylinositol-3- kinase, Rad, Glut4 and lipoprotein lipase mRNA levels in human muscle. J Clin Invest 98: 43-49

20. Frayn KN (1983) Calculation of substrate oxidation rates in vivo from gaseous exchange. J Appl Physiol 55: 628-634

21. Fery F, Balasse EO (1994) Glucose metabolism during the starved-to-fed transition in obese patients with NIDDM. Diabetes 43: 1418-1425

22. Chomczynski P, Sacchi N (1987) Single step method of RNA isolation by acid guanidinium thiocyanate-phenol-chloroform extraction. Anal Biochem 162: 156-159

23. Wang AM, Doyle MV, Mark DF (1989) Quantitation of mRNA by the polymerase chain reaction. Proc Natl Acad Sci USA 86: 9717-9721

24. Auboeuf D, Vidal H (1997) The use of the reverse transcription-competitive polymerase chain reaction to investigate the in vivo regulation of gene expression in small tissue samples. Anal Biochem 245: 141-148

25. Mc Pherson M, Quirke P, Taylor G (1991) PCR, a practical approach. Oxford University Press, New York

26. Pollare T, Vessby B, Lithell H (1991) Lipoprotein lipase activity in skeletal muscle is related to insulin sensitivity. Arteriosclerosis 11: 1192-1203

27. Caro JF, Sinha MK, Raju SM et al. (1986) Insulin receptor kinase in human skeletal muscle from obsese subjects with and without noninsulin-dependent diabetes. J Clin Invest 79: 1330-1337

28. Frederici M, Zucaro L, Porzio O et al. (1996) Increased expression of insulin/insulin-like growth factor-I hybrid receptors in skeletal muscle of noninsulin-dependent diabetes mellitus subjects. J Clin Invest 98: 2887-2893

29. Okabayashi Y, Maddux BA, McDoanld AR, Logson CD, Williams JA, Goldfine ID (1989) Mechanism of insulin-induced insulin receptor downregulation. Decrease of receptor biosynthesis and mRNA levels. Diabetes 38: 182-187

30. Mosthaf L, Vogt B, Häring HU, Ullrich A (1991) Altered expression of insulin receptor types A and B in the skeletal muscle of non-insulin-dependent diabetes mellitus patients. J Clin Invest 88: 4728-4730

31. Benecke H, Flier JS, Moller DE (1992) Alternative spliced variants of the insulin receptor protein: Expression in normal and diabetic human tissues. J Clin Invest 89: 2066-2070

32. Anderson CM, Henry RR, Knudson PE, Olefsky JM, Webster NJG (1993) Relative expression of insulin receptor isoforms does not differ in lean, obese and noninsulin-dependent diabetes mellitus subjects. J Clin Endocrinol Metab 76: 1380-1382

33. Wiersam MML, Auboeuf D, Nieuwenhuizen-Bakker IM, Radder JK, Riou JP, Vidal H (1997) Insulin receptor mRNA splicing and altered metabolic control in aged and mildly insulin-deficient rats. Am J Physiol 272: E607-E615

34. Garvey WT, Maianu L, Kennedy A et al. (1997) Muscle Rad expression and human metabolism: potential role of the novel Ras-related GTPase in energy expenditure and body composition. Diabetes 46: 444-450

35. Kahn BB (1992) Facilitative glucose transporters: Regulatory mechanisms and dysregulation in diabetes. J Clin Invest 89: 1367-1374

36. Kelley DE, Wing R, Buonocore C, Sturis J, Polonsky K, Fitzsimmons M (1993) Relative effects of calorie restriction and weight loss in noninsulin-dependent diabetes mellitus. J Clin Endocrinol Metab 77: 1287-1293

37. Björnholm M, Kawano Y, Lehtihet M, Zierath JR (1997) Insulin receptor substrate-1 phosphorylation and phosphatidylinositol 3-kinase activity in skeletal muscle from NIDDM subjects after in vivo insulin stimulation. Diabetes 46: 524-527

38. Baier LJ, Wiedrich C, Hanson RL, Bogardus C (1998) Variant in the regulatory subunit of phosphatidylinositol 3-kinase $(\mathrm{p} 85 \alpha)$ : preliminay evidence indicates a potential role of this variant in the acute insulin response and type 2 diabetes in Pima women. Diabetes 47: 973-975 